\title{
Foreign Direct Investment Strategy in International Marketing: The Case of Turkey
}

\author{
Asst. Prof. Dr. Mustafa Ercilasun (Beykent University, Turkey) \\ Asst. Prof. Dr. Ayşen Akyüz (Beykent University, Turkey) \\ Asst. Prof. Dr. Ayşe Saime Döner (Beykent University, Turkey)
}

\begin{abstract}
In recent years the role of foreign direct investments (FDIs) in economic development became very important for emerging economies. Thus, the competition to attract FDIs intensified. Turkey, being an emerging economy, needs to apply correct strategies to attract FDIs. This paper will consider competitive environment for FDIs around the world and evaluates steps taken by Turkey since the year 2000. In doing so, changing rules and regulations will be evaluated. After the experience of 2001 economic crisis, in 2003, Turkey passed Foreign Direct Investment Law and taken other actions to stimulate FDI's coming to the country. Changes in economic environment, political situation, legal framework and financial stability play roles in bringing inflow of FDIs. This paper will focus on the case of Turkey and will provide policy recommendations to increase the competitiveness in attracting FDIs.
\end{abstract}

\section{Introduction}

In order to understand how to attract FDIs it is important to understand factors influencing behaviors of existing corporations or corporations elevated to become international in selecting target countries and business environments they prefer to work. In this regard, doing business in particular country, preferred environment and business climate in a country is very important. In addition to economic factors such as cheap labor, location advantage general business climate is the most important for corporations selecting target countries. If Turkey, would like to attract FDIs it must evaluate all of these factors carefully and improve its business climate for foreigners. These improvements will reduce country risks of doing business abroad. Appropriate legal framework, rules and regulations, stable environments are a must to bring in FDIs.

Foreign direct investments by its nature are long run. Therefore stability helps to foresee the future with clarity. If political and business conditions are stable, not subject to change drastically over time, it helps to formulate business plans to succeed. Business plans need not be modified over and over. Stability is also important if it can provide security and guarantee. For example, governments may take over foreign-owned businesses, or may put some restrictions on expropriation of profits to home country. Countries with such an experience are not welcomed by potential FDI providers. The legal framework, need to provide guarantees for FDIs.

Turkey starting in 1980s changed its trade policies away from import substitution in favor of export promotion and moved toward trade liberalization. This drastic change in economic policy helped to accelerate its attractiveness for FDIs. Although economic policy shift happened in early 80s, rules and regulations changed slowly. During the adjustment process for development policy Turkey experienced some economic stagnations. Excluding the impact of latest global financial crisis, Turkey experienced its worst economic crisis in 2001. The collapse of some banks caused to take prudential measures to strengthening banking sector such as higher capital requirements. Since then, foreign banks percentage in Turkish banking sector increased. At the same time Turkey accelerated its privatization process. Some sizeable government enterprises such as Turk Telecom privatized. Privatization of state enterprises did not only brought in government revenues, but at the same time called for FDIs.

\section{Foreign Direct Investment}

Çavuşgil, Knight and Reisenberger (2012, p:434) defined foreign direct investment (FDI) as "an internationalization strategy where the firm establishes a physical presence abroad through direct ownership of productive assets such as capital, technology, labor, land, plant and equipment".

Foreign Direct Investment is the most convoluted and advanced market entry strategy entailing establishment of manufacturing plants, branches, etc. in target countries. Since, to establish physical presence, the company has to invest substantial amount of resources, FDI is riskier than other strategies like exporting or franchising (Çavuşgil, et. al., 2012)

There are numerous examples from Turkey that illustrate the examples of inward and outward FDI; such as Y1ldı Holding, Turkey's leading confectionary company acquired Belgium based chocolatier Godiva from American Campbell Soup Company which had earlier acquired Godiva or Russian Sberbank acquired Denizbank, a Turkish private bank, in 2012, since then Denizbank is controlled by Syberbank. 
When we look at the trends in the global economy we see that, companies from advanced and emerging markets are active in FDI and the target countries for such investments cover both the advanced and emerging markets. Companies from all types of sectors, services included, are taking a share from the FDI. For example major retailers began to perform activities across national borders in the 1970s including Carrefour (France), Metro AG (Germany) (Çavuşgil, et. al., 2012). Advanced economies such as United Kingdom, Japan and the United States have been popular destinations for FDI because they have strong GDP per capita; high GDP growth rates and density of knowledge workers in those countries are high.

Cavusgil et al (2012) states that managers pursue FDI strategies for different and complex reasons. Thus, they classified these reasons in three groups as "market-seeking motives", "resource/asset-seeking motives" and "efficiency-seeking motives". If we examine these motives in detail:

Market-seeking Motives: Focal companies may look for new opportunities abroad as a result of unfavorable local market conditions or they may be favorable opportunities in the foreign markets. So they may seek to gain access to new markets, they may follow their key customers abroad to prevent other suppliers from selling goods or service to them or to compete current or potential rivals directly in their home market.

Resource/asset-seeking motives: Some companies may desire to attain the resources or assets such as raw materials, knowledge, and technological and managerial know-how.

Efficiency-seeking motives: Some focal companies may seek to increase efficiency via FDI in operations and production by reducing sourcing and production costs by allocating cheap labor and other inputs to the production; by locating the plant facilities and assembly operations near the key customers, by taking advantage of the foreign government incentives and by avoiding trade barriers such as tariffs as these usually are applied only to exporting.

FDI activities can be classified by nature of the ownership (wholly owned direct investment, joint venture or equity participation) or by the form (greenfield investment, acquisition and merger).

Foreign direct investors choose their degree of control. This is accomplished through full -wholly owned direct investment in which the investor secures complete managerial control over its operations by assuming 100 percent ownership of the business or equity joint venture in which a separate firm is created through the investment by two or more parent firms- and partial -equity participation- ownership. On the other hand, when examining the classification by the form; Greenfield investment is a form of direct investment where a focal company starts a new venture in a foreign country by building new manufacturing plant or a new marketing or administrative facility from the ground up. An acquisition is the process of acquiring a company or facility. And a merger is a type of acquisition in which two companies join to form a new and a larger company (Cavusgil et al, 2012).

Hill (2009) states that, the majority of cross-border investment is in the form of acquisitions and mergers rather than greenfield investments. He indicates some reasons for that: First, mergers and acquisitions are quicker to execute compared to greenfield investment. Second, foreign companies are acquired because those firms have valuable assets such as strong brand loyalty, patents or distribution systems. Hence, it is simple and possibly less risky for a company to acquire those assets than to build them from the ground up. Third, companies involve in acquisitions because they believe that by transferring capital, management skills and technology, they can increase the efficiency of the acquired unit. FDI is expensive since a company must bear the costs of establishing production facilities across borders or of acquiring a foreign enterprise. It is risky because of the problems associated with different cultures and a focal company undertaking FDI in a foreign country for the first time is more likely to make mistakes.

Table 1 shows the top 10 non-financial multinational companies ranked by foreign assets dated 2013.

\begin{tabular}{|c|l|l|l|r|r|r|r|}
\hline Ranking by: & & & & \multicolumn{3}{|c|}{ Assets } & \multicolumn{2}{|c|}{$\begin{array}{c}\text { Sales } \\
\text { Industry }\end{array}$} & $\begin{array}{c}\text { Foreign } \\
\text { (millions } \\
\text { of } \\
\text { foreign } \\
\text { assets }\end{array}$ & \multicolumn{1}{|c|}{ Corporation } & Home economy & $\begin{array}{c}\text { Total } \\
\text { (millions } \\
\text { of } \\
\text { dollars) }\end{array}$ & $\begin{array}{c}\text { Foreign } \\
\text { (millions } \\
\text { of } \\
\text { dollars) }\end{array}$ & $\begin{array}{c}\text { Total } \\
\text { (millions } \\
\text { of } \\
\text { dollars) }\end{array}$ \\
\hline 1 & General Electric Co & United States & Electrical \& electronic equipment & 331160 & 656560 & 74382 & 142937 \\
\hline 2 & Royal Dutch Shell plc & United Kingdom & Petroleum expl./ref./distr. & 301898 & 357512 & 275651 & 451235 \\
\hline 3 & Toyota Motor Corporation & Japan & Motor vehicles & 274380 & 403088 & 171231 & 256381 \\
\hline 4 & Exxon Mobil Corporation & United States & Petroleum expl./ref./distr. & 231033 & 346808 & 237438 & 390247 \\
\hline 5 & Total SA & France & Petroleum expl./ref./distr. & 226717 & 238870 & 175703 & 227901 \\
\hline 6 & BP plc & United Kingdom & Petroleum expl./ref./distr. & 202899 & 305690 & 250372 & 379136 \\
\hline 7 & Vodafone Group Plc & United Kingdom & Telecommunications & 182837 & 202763 & 59059 & 69276 \\
\hline 8 & Volkswagen Group & Germany & Motor vehicles & 176656 & 446555 & 211488 & 261560 \\
\hline 9 & Chevron Corporation & United States & Petroleum expl./ref./distr. & 175736 & 253753 & 122982 & 211664 \\
\hline 10 & Eni SpA & Italy & Petroleum expl./ref./distr. & 141021 & 190125 & 109886 & 152313 \\
\hline
\end{tabular}

Table 1: Top 10 Non Financial Multinational Companies ranked by foreign assets Source: Adapted from UNCTAD website 
Czinkota et al (2005) mentions about the positive impacts of FDI on host countries. According to Czinkota et al (2005), capital flows are beneficial to the host countries with little indigenous sources and restricted opportunities to raise capital in the world markets. Technology and management skills transfer are two other reasons why the host countries are welcoming inward investments. At the company level, FDI may increase competition and this, ultimately may be beneficial to the economy as well as to consumers by increased productivity and possibly with lower prices. Besides, import substitution, export earnings and etc. all help the host country on the trade account side of the balance of payments. Job opportunities and salary payments over the market rates are the other important advantages of the FDI on host country.

On the other hand, FDI has some possible negative impacts too. Investors usually want to concentrate their research and development efforts and especially their fundamental research. With the technological expertise, the investor can assist the host nation's economic development; however it may leave the host country contingent upon the multinational company, on flows of new technology. Also the multinational company may attract highly skilled local employees from the host country to its central research facility and engage in the brain drain. Czinkota et al (2005), also remarks that the economic benefits of FDI may be questionable as well. Capital inflows may be followed by outflows in a higher degree. Governments also see the foreign investors as a disturbance to their economic planning. Host nations do not look approvingly on an investor that may want to keep the import content high. And the cultural factors may create negative impact on the host country.

The positive and negative impacts that concern the host countries also apply to the home country. FDI means a contribution to the focal company's home market's GDP from profits, royalties and fees sent from affiliates. It could lead to expanding export markets and it could serve for political motives as well. The major critical issue is concerning employment, not only job losses are in question but also effects on export and imports. Another negative issue is that of technological advantage. For instance, sharing the technological expertise with foreign entities could lead the home country to a loss of its competitive position in world market place. Arguments for and against FDI are countless. Costs and benefits must be put in the balance. Only the host and home countries can assess benefits against cost. (Czinkota et al, 2005). Hill (2009) mentions that when doing the assessment for the home country, we should take international trade theory into consideration. According to international trade theory, home country's anxiety about the unfavorable negative effects of offshore production may be positioned wrongly. Offshore production states the FDI is undertaken to serve the home market. Such FDI may stimulate economic growth and employment in the home country by setting the home country resources free to concentrate on activities that the home country has comparative advantage about. Besides, home country citizens could benefit if the price of a product falls due to the FDI.

Many countries implement policies to attract foreign direct investment. Incentives to promote such investments are fiscal, financial and non-financial. Fiscal incentives are specific tax deals that typically consist of tax rebates, special deductions for capital expenditures, special depreciation allowances, designed to attract the foreign investor. Financial incentives offer financial support by providing assets such as a land or loan. And nonfinancial incentives can cover special promotion through tariffs, quotas, and local content requirements and investments in infrastructure facilities (Czinkota et al, 2005).

\section{FDI Regulations in the World and in Turkey}

Host countries apply policies both to restrict and to support inward FDI. Government incentives such as tax concessions or subsidies are offered to foreign companies to attract investment. On the other hand, host nation's governments use a wide range of controls to restrict inward FDI. Ownership restraint is one way of control and can take several forms. Governments exclude foreign investors from certain industries related to national security or competition. They may do that also for protecting infant industries. Besides, they help maximize the resource transfer effect and employment benefits that are associated with FDI. In Japan for example, until the early 1980s, most FDI was prohibited unless the foreign firm had valuable technology. Then, the foreign firm was allowed to form a joint venture with a Japanese company because the Japanese government believed that such an arrangement would speed up the diffusion of the technology throughout the Japanese economy.

Performance requirement is also used to restrict FDI and can also take several forms like ownership restraint. The most prevalent performance requirements are related to exports, technology transfer and the local participation in top management. Besides, performance requirements are used to maximize the benefits and minimize the costs of FDI for the host country. Many countries apply some form of performance requirements but they tend to be common in less developed countries (Hill, 2009).

In considering political system of a country for doing business political stability of selected country appears to be the most important. Political system defined by the form of a government. Two extreme cases are democracies and dictatorships. However, more than the form of government, stability and being able to create influence to change regulations via special interest groups that exists come forward. Thus, existences of special interest groups are very helpful. Trade associations, environmental consumer groups, civil groups for liberalization and freedom are examples of some special interest groups. These groups do not only serve to 
promote improved trade and FDIs but also serve as a source for market information and facilitator to market entry.

During the early period of Turkish Republic, following the İzmir Economics conference, liberal economic policies adopted. In1924, Turkey passed a law allowing foreigners to acquire property. Until about mid-thirties number of multi-national corporations increased, particularly in banking, finance and insurance fields (Tezel 2002). However, the levels of domestic and foreign investments were not satisfactory. Thus, government changed its course toward Étatism, and engaged directly with economic activities. Up until 1950s, public state enterprises founded and operated by government and railroad projects implemented. During this period foreign investments declined significantly, partly due to World War II. After the war is over and Turkey transitioned to multi-party system incentives to stimulate foreign investments considered. In 1954, with the acceptance of Foreign Capital Law, foreigners allowed to enter into private sector, provided that they will not have monopoly power and special privileges as long as their investments considered contributing to the economic development of a country (Erçakar and Karagöl, 2011, p9). Although FDIs increased, this particular law was open to conflicting interpretations and was not clear. Foreign investors came in via partnership, in the areas of food processing, automotive, pharmaceutical and appliances. In 1963, with the establishment of State Planning Organization, Turkey entered into planned economic development era. Order number 17 declared. With this declaration, except petroleum area, foreigners can establish joint partnerships provided that they bring in primary capital as a foreign exchange. However, they were not allowed to transfer profits abroad. In practice, from time to time, governments got around this particular decree with other decrees.

The level FDIs coming in Turkey is shown in figures 1-3. It's obvious from Figure 1 that in early periods FDIs coming in Turkey did not reached to significant levels although we observed increasing trend with transition to planned economy era after 1963. Figure -2 shows that during 1970s FDIs were at low levels and impacted negatively from 1974 and 1979 recessions. After 1979, it jumped to above 100 million dollars.

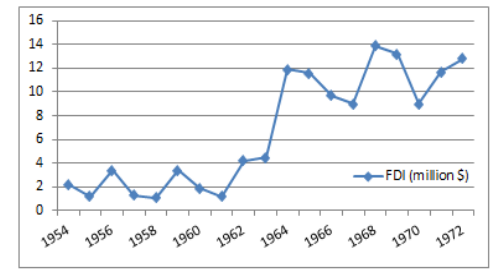

Figure 1: FDIs Period: 1954-1972

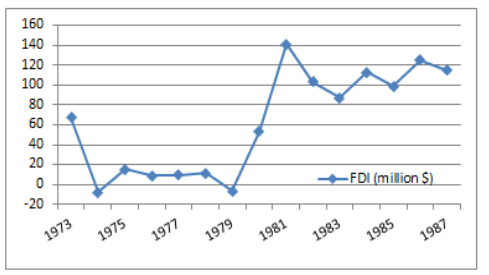

Figure 2: FDIs Period: 1973-1987

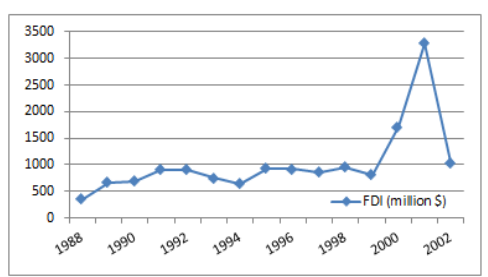

Figure 3: FDIs Period: 1988-2002

\begin{tabular}{|l|r|r|r|r|r|r|r|r|r|r|r|r|r|r|r|r|}
\hline Year & 1954 & 1955 & 1956 & 1957 & 1958 & 1959 & 1960 & 1961 & 1962 & 1963 & 1964 & 1965 & 1966 & 1967 & 1968 & 1969 \\
\hline FDI (million \$) & 2,2 & 1,2 & 3,4 & 1,3 & 1,1 & 3,4 & 1,9 & 1,2 & 4,2 & 4,5 & 11,9 & 11,6 & 9,7 & 9 & 13,9 & 13,2 \\
\hline Year & 1970 & 1971 & 1972 & 1973 & 1974 & 1975 & 1976 & 1977 & 1978 & 1979 & 1980 & 1981 & 1982 & 1983 & 1984 & 1985 \\
\hline FDI (million \$) & 9 & 11,7 & 12,8 & 67,3 & $-7,7$ & 15,1 & 8,9 & 9,2 & 11,7 & $-6,4$ & 53 & 141 & 103 & 87 & 113 & 99 \\
\hline Year & 1986 & 1987 & 1988 & 1989 & 1990 & 1991 & 1992 & 1993 & 1994 & 1995 & 1996 & 1997 & 1998 & 1999 & 2000 & 2001 \\
\hline FDI (million \$) & 125 & 115 & 354 & 663 & 684 & 907 & 911 & 746 & 636 & 934 & 914 & 852 & 953 & 813 & 1707 & 3288 \\
\hline
\end{tabular}

Table 2: FDI Inflows During 1954-2001 Source: Treasure Department of Turkey

After 1980, liberalization and export promotion periods, Turkey observed increased FDI levels. However, FDI levels did not increased significantly, despite new mode of trade and accession to Customs Union with European Union in 1995. As Turkey approached to year 2000 it observed significant increase in FDI levels, but this jump hampered by 2001 economic crisis. During 1990s the collapse of Eastern Block, China and Far Eastern countries become potential destinations for FDIs along with some emerging Latin American countries. Turkey was not in a position to compete with these countries both on economic and regulatory fronts. 1980 with the new decree Foreign Capital Directorate established. This was a significant turning point.

With the passage of Foreign Direct Investment Law in 2003 (FDIL-2003), Turkey experienced significant increase in FDI inflows till 2006. Some of this increase could be attributed to expansionary economic policies of western countries, particularly United States. After 2007 as the world entered global economic crisis FDIs flowing out of these countries declined. Turkey also took its share from this declining trend of FDIs as it is shown by Figure 4. 


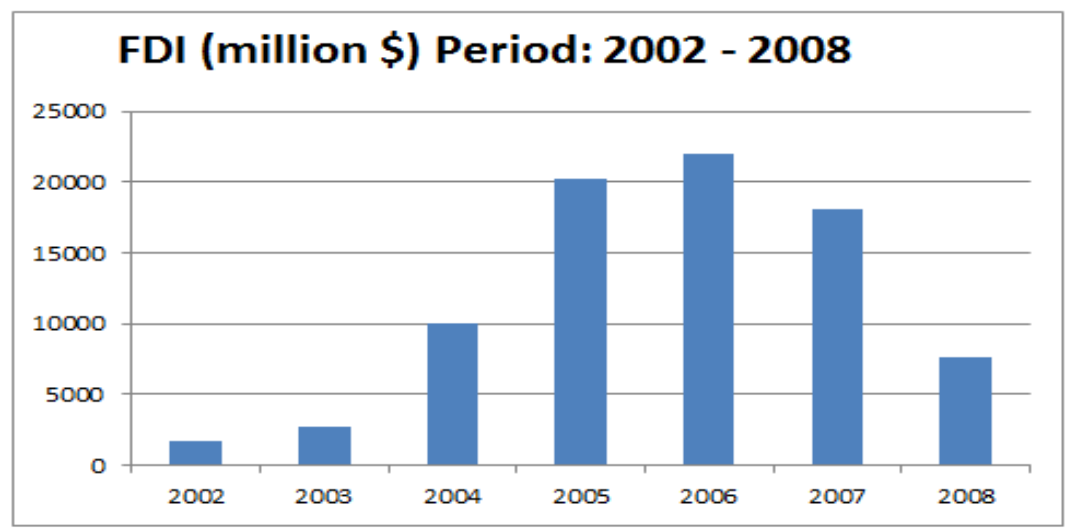

Figure 4: Foreign Direct Investments 2002-2008 Source: Ernst \& Young, 2013.

According to with FDIL-2003 foreign investors are subject to equal treatment with domestic investors and protected against expropriation and nationalization. Furthermore, they can freely transfer profits, dividends and other payments received as a result of their activities in Turkey. Additionally foreign investors were no longer required to obtain pre-license to business in Turkey. Instead of granting permission to foreign operations in Turkey, monitoring their activities is chosen as a new strategy.

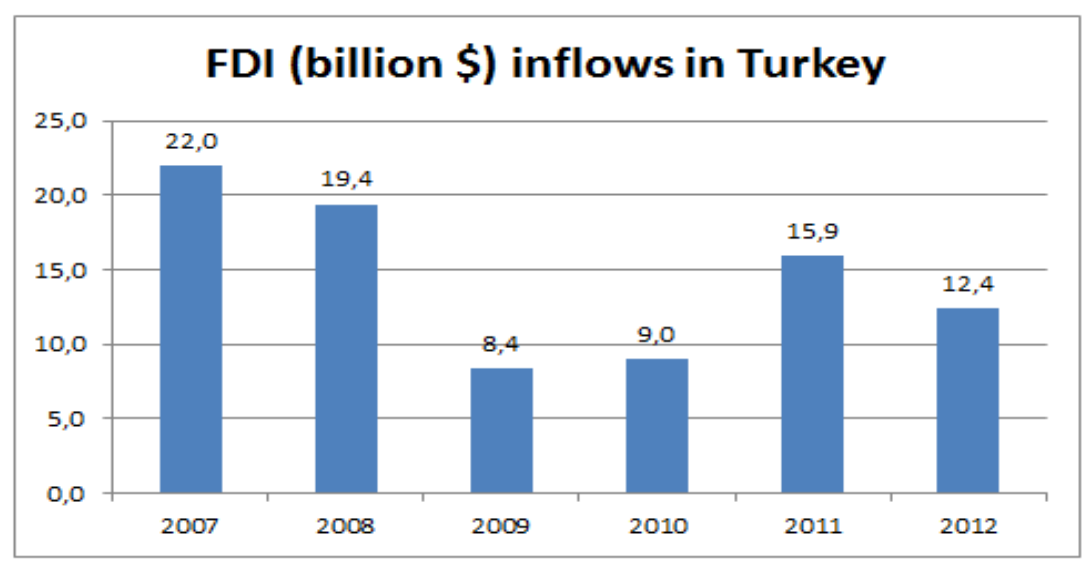

Figure 5: Foreign Direct Investments 2007 - 2012 Source: Ernst \& Young, 2013

Figure 5 adopted from Ernst \& Young's Attentiveness Survey. It shows that Turkey improved its FDI inflow situation after the global economic crisis. In 2011 FDIs increased by 76 percent against the prior year. However, in 2012 FDI declined again due to cross-border decline in merger \& acquisitions (Ernst \& Young, 2013). According to the same survey respondents asked the following question. In your opinion, where should Turkey concentrate its efforts to increase its attractiveness in global competition? Reduced government bureaucracy with $38 \%$ was the highest scored attribute. Other important attributes that come forward support SMEs, reduce taxation, increase tax benefits \& incentives, facilitate access to credit, and increase flexibility of labor regulations (Ernst \& Young, 2013).

FDI inflows coming in Turkey for years of 2013-14 differs depending upon the sources considered. According to Investment Support \& Promotion Agency of Turkey for 2013 expected FDI inflow was $\$ 13.7$ billion (Bloomberg, 2014). International net direct investments in Turkey totaled $\$ 8.6$ billion in the first eight months of 2014, a 9.8 percent increase from the same period of the previous year, the Economy Ministry announced on Oct. 27 (Hürriyet Daily News, 2014).

In 2012, Turkey declared new investment incentive scheme. These incentives used various support instruments:

$\checkmark \quad$ VAT Exemption

$\checkmark$ Customs Duty Exemptions

$\checkmark$ Tax Reduction

$\checkmark$ Social Security Premium Support (both employer \& employee shares)

$\checkmark \quad$ Income Tax Withholding

$\checkmark$ Interest Rate Support

$\checkmark$ Land Allocation

$\checkmark \quad$ VAT Refund

Different levels of incentives provided depending upon the region where the FDIs are directed. Turkey is divided into six regions from 1 through 6, where region 1 receives lowest level of incentive. As the region 
number increased the level of incentive also increases. For example tax reduction rate for region 1 is 50 percent and for region 6 it is 90 percent (invest.gov.tr).

Figure 6 shows FDIs as percentage of GDP for Turkey and how it stands with comparable countries. Compared to other emerging markets (Brazil, Mexico, Poland, and Czech Republic), Turkey's FDI performance stands out poorly.

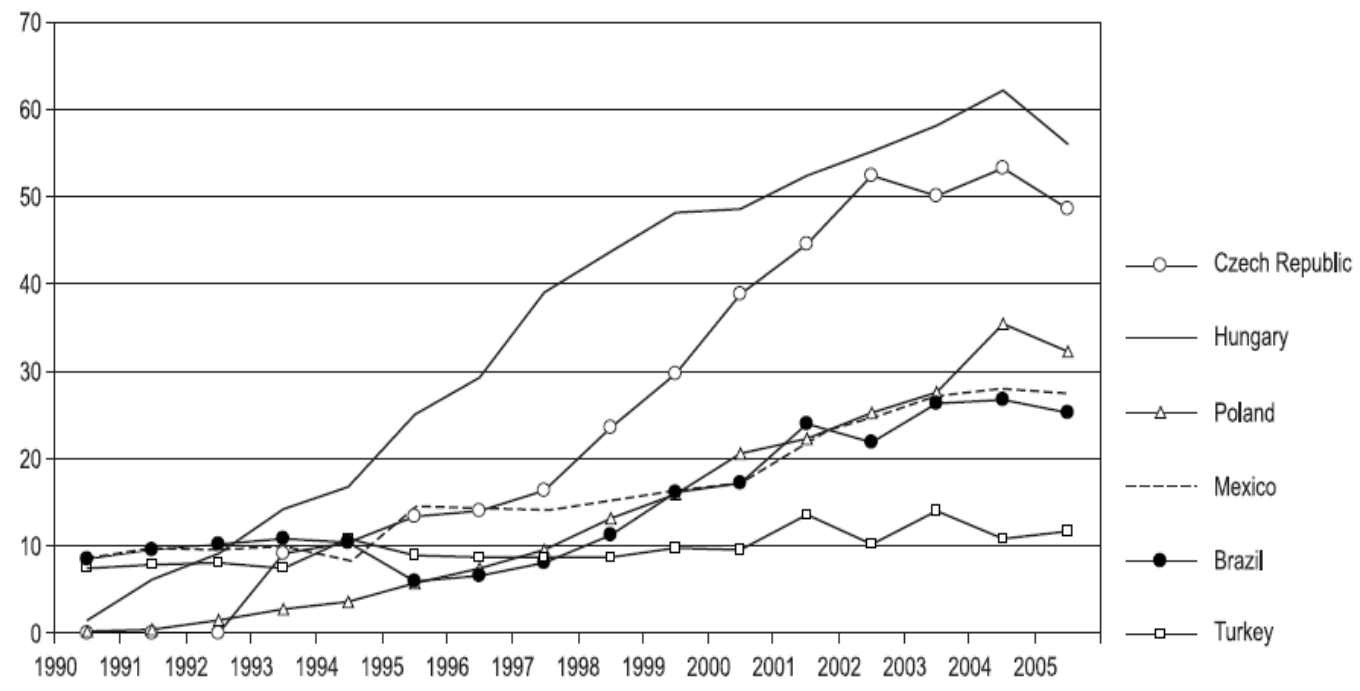

Figure 6: Percentage of FDI inflow in GDP for selected emerging market economies. Source: UNCTAD 2006, adopted from Dumludağ, Devrim, 2009

The relatively poor performance of Turkey could be explained by various factors. Possibly besides economic and political stability factors some other institutional factor are also playing a role. Intuitional factors are informal and formal rules and enforcement mechanism (Dumludağ, 2009).

\section{Conclusions}

In accordance with the literature and statistics reviewed, Turkey tried to attract FDIs from abroad. In early periods of the Turkish Republic protective import substitution and trade policies prevented Turkey to attract significant levels of FDIs. Trade liberalization policies implemented in 1980s was a turning point for igniting FDIs coming in Turkey. However, initially Turkey was not successful in stimulating inflow of FDIs due to lack of experience and deficiencies in its regulatory structure and fluctuating business cycles. Accelerated inflationary periods followed by couple of economic recessions during 1990s and worst crisis 2001 and lastly 2008 global financial crises negatively impacted FDI inflows. Fortunately prudent measures taken after 2001 economic crisis and political stability established after 2002, the passage of Foreign Direct Investment Law in 2003 opened opportunities for Turkey to attract FDIs. Additionally Turkish effort to modify various laws to align those European Union standards was helpful. Furthermore global expansion happening during 2000s was blessing for increased FDIs up until 2008 global crisis. Like many other countries the latest economic crises fractured FDI inflows coming into the country. Turkey slowly came out of this stagnation, but worsening balance of trade position and increased foreign debt levels, coupled with still stagnating Europe, particularly in periphery countries slowed economic growth and FDI inflows. Despite upon these negative factors Turkey's effort to attract FDIs deserve applause. However the road to make Turkey attractive for FDI heaven in the globe requires further actions. It is important to eliminate bureaucracy and informal sector. In Earnt \& Young survey bureaucracy came out to be the number one desired area for improvement. Reduction in informal sector will eliminate unfair competition for potential investors from abroad. Improvement in legal system and accelerated court processes should be considered. Increased productivity and flexibility in the labor market along with better labor regulations will help to stimulate FDIs. Addionally, transparent economic policy that would eliminate surprises and help to manage future expectations of businesses contribute to stable economic outlook. This outlook supported with political stability will further strengthen attractiveness for FDI inflows. 
Appendix:

\begin{tabular}{|l|l|}
\hline \multicolumn{1}{|c|}{ Year / Date } & \\
\hline 1954 & Foreign Capital Law passed \\
\hline 1963 & State Planning Organization Founded \\
\hline 1974 and 1999 & Economic Crisis \\
\hline 1995 & Custom Union Accession \\
\hline January 1980 & Declaration of Liberalization Policies for Free Trade \\
\hline 1980 & $\begin{array}{l}\text { Foreign Capital Directorate established. } \\
\text { Free Trade Zone Directorate founded. }\end{array}$ \\
\hline 1982 & $\begin{array}{l}\text { Incentives for tourism establishment declared. } \\
\text { Financial Leasing Rules written. }\end{array}$ \\
\hline 1985 & Restrictions to acquire real estate lifted. \\
\hline 1994 & Protection of Competition Law \\
\hline 1995 & $\begin{array}{l}\text { Protection of patent rights } \\
\text { Protection of Brands } \\
\text { Protection of Customers }\end{array}$ \\
\hline 2001 & Economic crisis \\
\hline 2001 & Turk Telecom privatization \\
\hline 2003 & Foreign Direct Investment Law passed \\
\hline
\end{tabular}

Table A1: Significant Events Related to Foreign Direct Investments

\section{References}

- Bloomberg (2014) : http://www.bloomberg.com/news/articles/2014-03-26/turkey-2014-fdi-seen-meetinglast-year-level-amid-graft-probe (viewed 07.06.2015)

- Cavusgil, S.T., Knight, G. , Riesenberger, J.R. (2012). International Business. New Jersey: Pearson. Second Edition

- Czinkota, M.R., Ronkainen, I.A., Moffett, M.H. (2005). International Business. USA: South-Western, Thompson. Seventh Edition.

- Dumludağ, Devrim (2009) “An Analysis of the Detarminants of Foreign Direct Investment in Turkey: The role of the Institutional Context”. Journal of Business and Management. 10:1, p 15-30.

- $\quad$ Ernst \& Young's Attentiveness Survey: Turkey 2013

- Erçakar, M. E. and Karagöl, E. T. (2011). Türkiye'de Doğrudan Yabancı Yatırımlar. Seta Analiz.

- Hill, C.W.L (2009). Global Business Today. New York: McGraw-Hill. Sixth Edition.

- Hürriyet Daily News (2014): http://www.hurriyetdailynews.com/fdi-inflow-to-turkey-rises-by-10-percentin-2014-----aspx?pageID $=238 \& n I D=73524 \& N e w s C a t I D=345$ (viewed 07.06.2015)

- Tezel, Y.S. (2002). Cumhuriyet Döneminin İktisadi Tarihi (1923-1950). İstanbul: Tarih Vakfi Yurt Yayınları.

- UNCTAD. (2006). United Nations Conference of Trade and Development. Handbook of Statistics UNCTAD: http://www.unctad.org/Templates/Page.asp?intItemID=1584\&lang=1 (viewed 07.06.2015)

- UNCTAD.(2013). United Nations Conference of Trade and Development. Handbook of Statistics UNCTAD: http://unctad.org/Sections/dite dir/docs/WIR2014/WIR14 tab28.xls (viewed 07.06.2015)

- $\quad$ Ünay, S.(2013). Modern Kalkınmacılık. İstanbul: Küre Yayınları. 